\title{
Keeping the Horn on the Rhino. A Study of Balule Nature Reserve
}

Elisa Reuter ${ }^{1} \&$ Lieselot Bisschop ${ }^{2}$

Reuter, E. \& Bisschop, L. (2016). Keeping the horn on the rhino. In G. Potter \& A. Nurse (Eds.), Geography of Environmental Crime. London: Palgrave Macmillan, p. 149-186.

Since 2007, rhinoceros poaching in South Africa has been increasing, now averaging three rhinos per day. Protecting the remaining rhinos requires both a better understanding of the crime of rhino poaching and of anti-poaching strategies. Through a theoretical triangulation of routine activity (Cohen \& Felson, 1979), rational choice (Cornish \& Clarke, 1986), and situational crime prevention theories (Clarke, 1997), we aim to better understand the crime of rhino poaching and analyze whether and how situational prevention measures can alter the cost-benefit equation of potential offenders. We also pay attention to how the sociopolitical and economic context affects rhino poaching and its governance. This chapter presents the results of research relating to the rhino conservation model of the Balule Nature Reserve in South Africa. Our study is based on participatory observation in their anti-poaching program, as well as interviews with stakeholders and partners of the program. We examine the Balule Rhino Conservation Model's organizational design and the counter-measures currently employed. This allows us to assess strengths and weaknesses of the model and provide recommendations for improvement, both for this case and for other anti-poaching contexts.

Key words: rhino, poaching, wildlife crime, situational crime prevention theory, environmental governance

\section{Introduction}

Wildlife trafficking, as a form of transnational environmental crime, is a lucrative illicit endeavor that is rivaled only by trafficking in arms, humans, and drugs. The illegal trade in wildlife, timber, and fish is worth approximately 10 to 15 billion US dollars annually (Braun 2012). Poaching of animals is a threat to the livelihood of local communities, which depend on wildlife tourism. In

\footnotetext{
1 Investigator at the UN Office of Internal Oversight \& Visiting researcher at Governing and Policing Security, Faculty of Economics, Ghent University, Belgium - elisa1reuter@gmail.com

2 Postdoctoral Research Fellow of the Research Foundation Flanders at Ghent University, Belgium \& Assistant Professor at Erasmus University Rotterdam, the Netherlands - lieselot.bisschop@ugent.be
} 
2012, the US Secretary of State Hillary Clinton labeled poaching a national security threat (rather than a mere conservation issue) and advocated for more law enforcement training and expertise to stem the surge of poaching (Braun 2012; Rhino Mercy 2013). Undercover investigations have shown that the proceeds of wildlife poaching are currently financing terrorist organizations (e.g., Lord's Resistance Army, Al Shabaab, see Kalron \& Crosta 2013; Christy \& Stenton 2015). Calls for integrated anti-poaching and wildlife trafficking approaches have led to the emergence of multistakeholder initiatives and public-private partnerships (Johannesen \& Skonhoft 2004; Poudyal, Rothley \& Knowler, 2009; Hauck \& Sweijd 1999). Despite these initiatives, the poaching of rhinos in South Africa continues unabated and is occurring through the use of increasingly sophisticated methods. In fact, poaching numbers have increased from a few per year to three a day.

Poaching of rhinos and other species is influenced by different factors such as political instability in neighboring countries (e.g., Zimbabwe) (Baral 2013), public mismanagement resulting in persisting poverty and hyperinflation (Artz 2014), and a lack of other opportunities to earn a living (Kvinta 2014). Moreover, embassy employees traffic wildlife (products) in diplomatic shipments (Animal Rights Africa 2009) and the sport hunting community arranges illegal rhino hunts for trophies (Rademeyer 2012b). Prosecution and sentencing only started in the last couple of years; prior to this, wildlife criminals only received a proverbial slap on the wrist (Rademeyer 2012a). Organized crime syndicates operate largely undetected and undisturbed in South Africa, feeding the demand for wildlife products on the black market (Rademeyer, 2012c; Warchol, 2004). These poaching syndicates are a threat to rangers, tourists, and local inhabitants. Poaching threats also shift the tasks of wardens from pure conservationists and managers to quasi-law enforcement entities, necessitating a range of counter-measures both in Kruger National Park (KNP) and the neighboring private nature reserves. Most of these measures are costly, with the majority of funding coming from charities and donations.

The significant rise in poaching has led to discussion among conservationists, and law enforcement and government institutions about preferred anti-poaching measures. Some have suggested a shoot-to-kill policy concerning suspected poachers (Leader-Williams \& MilnerGulland, 1993; Messer 2000, 2010; DeFranza, 2010), whereas others support the legalization of the rhino horn trade and flooding of the market with horns from stockpiles (Sharife, 2013; Ammann, 2013; Biggs, Courchamp, Martin, \& Possingham, 2013; Sills, 2013). Protecting the remaining rhinos definitely requires a better understanding of poaching and of anti-poaching strategies. To this end, this study explores a conservation model put in place at Balule Nature Reserve, a medium-sized reserve in the Greater Kruger National Park (GKNP) in South Africa. Through a theoretical triangulation of routine activity (Cohen \& Felson, 1979), rational choice 
(Cornish \& Clarke, 1986), and situational crime prevention theories (Clarke, 1997), we aim to better understand the crime of rhino poaching and analyze whether and how situational prevention measures can alter the cost-benefit equation for potential offenders.

This research begins with a literature review on wildlife crimes in both green and environmental criminology. Following this is a methodological description of the case study. We then use routine activity, rational choice, and situational crime prevention theories to analyze the causes of rhino poaching. Whereas this etiological question is answered with regard to all rhino habitats, the following section focuses specifically on the Balule Nature Reserve case study. We pay attention to the sociopolitical context, make a poaching risk assessment for the reserve, discuss the organizational design of the multi-stakeholder anti-poaching initiative, and analyze what situational prevention measures exist. The discussion outlines several strengths and weaknesses of the conservation model, which inform recommendations for improving the Balule conservation model and other anti-poaching contexts provided in the subsequent section. The conclusion discusses this case study in the broader context of environmental crime.

\section{Literature review}

\subsection{Wildlife crime and green/conservation criminology}

Humanity's unsustainable use of natural resources has led to the extinction of species and the pollution of ecosystems (Oskamp 2000; South, Brisman, \& Beirne, 2013). Causes can be found in historical and cultural developments or traditions, as well as acts of negligence by corporate and government entities (Faure, 2009). Not all environmentally harmful acts are criminalized, especially when powerful actors such as governments or corporations lobby to spare certain groups of perpetrators from prosecution (White 2011). There is no doubt that wildlife crime and rhino poaching are criminal acts that are harmful to society and to animals themselves. Hence, wildlife poaching and trafficking are core topics within green and conservation criminology (Gibbs, Gore, McGarrell, \& Rivers III, 2009; White 2011; Wyatt 2009).

The notion of harm is not as straightforward for wildlife crime as for crimes of theft or physical harm committed in human vs. human relationships (Beirne \& South 2007). Undoubtedly, these animals experience tremendous suffering, harm, and loss of life at the hands of wildlife criminals. However, they are not legally considered victims and are regarded as property rather than individuals. The victimization is transferred to present and future populations of humans, who will lose these iconic animals through extinction. Also, income from ecotourism connected to this particular species must be considered. The anthropocentric definition of harm has been criticized (Beirne 2013; Sollund 2013) because juxtaposing animals and humans implies that 
"they were different in aspects which are important in attributing rights or capacities such as intelligence, sentience and morals and the ability to feel pain and pleasure" (Sollund, 2013, p. 2). Lacking a comprehensive term for humans killing animals, Beirne (2013, p.63) coined the term "theriocide." The current state of affairs concerning rhino poaching is far from recognizing rights of these animals. Species justice is not in place yet and may come as "too little, too late" for some non-human species, including rhinos.

In our study, wildlife crime is defined as "the taking, trading, exploiting, or possessing of the world's wild flora and fauna [...] in contravention of national and international laws" (Interpol, 2010). This definition aligns with the Convention on International Trade on Endangered Species of Wild Flora and Fauna (CITES) and South Africa's domestic criminal environmental laws. Taking into account that CITES is not a legal document per se but is designed and intended to promote national legislation, rhino poaching is considered a national crime violating South African legislation. Which South African law applies depends on the location of the crime, but the country nonetheless considers rhino poaching a criminal act. While national legislation applies to national parks and other protected areas, private game farms fall under local environmental management acts. The laws relevant for Balule Nature Reserve list restricted activities, one of which is poaching. Possible penalties are prison sentences up to ten years and/or a fine of up to 10,000,000 ZAR (approximating EUR 636,000 or USD 716,000, see The Law Library, 2014). The key words here are "up to," at least regarding fine amounts. Rhino poachers can also be charged with violations under the Firearms Control Act 60 of 2000 and its subsidiary legislation of 2004. The sentence can be a fine or a prison term between 2 and 25 years, but statistics concerning its application have not been released since the act came into force (The Law Library, 2014).

Although we use a legalistic definition of poaching, we also pay attention to the harmful consequences of poaching at a social and economic level. South Africa's tourism industry, which supports one in every twelve jobs, largely depends on the visibility and existence of wildlife in its territory (Brand South Africa 2012). If poaching continues to threaten wildlife in South Africa and to compromise the safety of visitors, employment opportunities in the tourism industry and related fields (e.g., the security sector, restaurant and food supplies, arts and crafts, car rental) will decrease. This would result in South Africa losing a substantial portion of its annual gross domestic product.

\subsection{Wildlife crime and environmental criminology}

The Chicago school of research in sociology and criminology coined the term "environmental criminology." In this case, environmental means that research focuses on the spatial, contextual, and immediately-surrounding situational factors that can influence criminal activities. In this 
approach, the environment does not refer to nature, and environmental criminology does not necessarily focus on environmental harm. When this situation-focused approach emerged, it shifted criminological attention away from the offender to the context. The realization followed that measures altering the situation may be suitable to prevent the crime. These approaches are mostly used in understanding and preventing street crimes such as burglary and car theft. More recently, they have been applied to wildlife crimes such as parrot poaching and illegal fishing (Pires \& Clarke, 2012; Pires \& Moreto, 2011; Clarke \& De By, 2013; Petrossian 2012, 2014). The situational focus is therefore not new, but is rather being applied to a new topic.

We use situational crime prevention theory (SCPT) to better understand the factors influencing rhino poaching and to evaluate the measures employed at Balule Nature Reserve. SCPT builds on routine activity (Cohen \& Felson, 1979) and rational choice theories (Cornish \& Clarke, 1986) and stresses the importance of the immediate environment and available opportunities in offender decision-making.

In line with routine activity theory (Cohen \& Felson, 1979), we examine rhino poaching as a direct-contact crime of commission, as offenders display brutality, cruelty, and violence. Crime is considered to occur with the convergence of a motivated offender, a suitable target, and an absence of available and capable guardians. The motivation of the offender is accepted as a given. Value, inertia, visibility, and accessibility enable assessment of the suitability of the target. Guardians can be anyone (not just governments) and may be absent in fact or in perception. This theory has been successfully applied to better explain and understand the phenomenon of (sustenance) poaching. Herbig and Warchol (2011) used routine activity theory to examine rhino poaching, and thereby contributed to understanding of why game reserves and protected areas are continuously violated by poachers.

In line with rational choice theory (Cornish \& Clarke, 1986, 2003; Clarke 2000; Cohen 2000), we analyze offenders' cost-benefit analysis against situational influences. This analysis assumes that offenders are reasoning individuals who weigh perceived risk, anticipated effort, and potential rewards of a crime. When illegal means are the most suitable route of action, they start searching for opportunities.

Situational crime prevention theory assumes that, despite unidentified offenders, reducing opportunities will lead to a decrease in crime. SCPT suggests that a variety of measures can alter the perceived risk, anticipated effort, and potential reward within the offender's cost-benefit analysis. These measures are seemingly simple and practical (Cornish, 1994, p. 153), but must be tailored to the crime and the context (Cornish \& Clarke 1987). SCPT has been successfully applied to wildlife crime and poaching in particular (Clarke \& De By, 2013; Pires \& Clarke, 2012; 
Pires \& Moreto, 2011). Huisman and van Erp (2013) applied SCPT to environmental white-collar crime and found it useful for identifying opportunity structures. However, they noted that SCPT should not be considered a panacea for all environmental crimes, because it was designed to combat crimes of commission. In contrast, many environmental crimes are crimes of omission (e.g., waste crime).

With this triangulated theoretical approach, we hope to increase understanding of rhino poaching, while also providing a more complete picture than is available when looking only at the situational context and prevention methods at the chosen nature reserve.

\section{Method}

The field research was performed at Balule Nature Reserve in the Maruleng municipality of the Limpopo Province of northeast South Africa. This medium-sized private reserve with approximately 500 square kilometers of bush is located on the western edge of the GKNP area. The land was previously used for cattle farms, which were replaced by game reserves and hunting concessions in 2006 and transformed to the nature reserve in 2013. White South Africans and foreign landowners are the exclusive owners.

The reserve is home to the "big five" 3 and many animal populations traverse the area. Timbavati Nature Reserve and Klaserie Nature Reserve border the reserve, which then tie into Kruger National Park (KNP) further to the east. All these reserves are fenceless on their borders with each other and KNP. This benefits wildlife movement and the ecosystem. At the same time, this is a challenge for anti-poaching projects because there is no marking of old fence lines, resulting in easy crossing of jurisdictional boundaries, requiring cooperation between different antipoaching entities, and coordination of joint operations.

\footnotetext{
${ }^{3}$ African elephant, the lion, the leopard, the rhinoceros and the African buffalo
} 


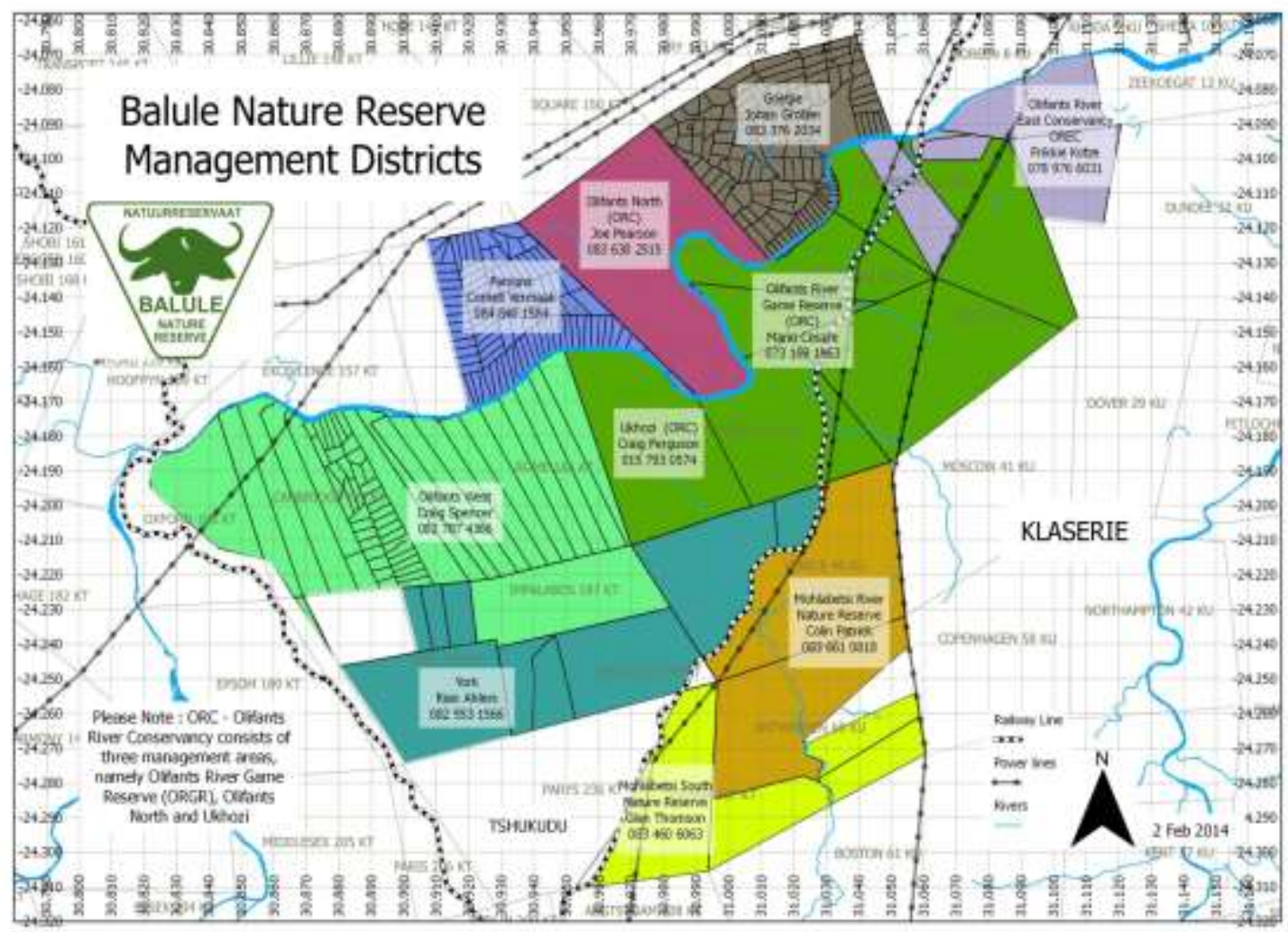

As shown in Figure 1, Balule Nature Reserve is currently divided into nine management sections: Parsons (PNR), Olifants North (ONNR), Gritjie (GNR), Olifants East (OENR), Olifants River (ORNR), Olifants West (OWNR), York (YNR), Mohlabetsi River (MRNR), and Mohlabetsi South (MSNR). For each subsection, one warden coordinates conservation, reserve, and tourism management efforts as well as anti-poaching measures and reports to the Head Warden of Balule Nature Reserve.

Poachers have targeted Balule Nature Reserve itself and the surrounding areas. After identifying a need for a comprehensive response, Olifants West Nature Reserve (OWNR) in partnership with Rhino Mercy, TransFrontier Africa (TA), Pro-Track, Endangered Wildlife Trust (EWT), and South African National Parks (SANParks) created a local initiative to counter poaching threats. OWNR is the region that has spearheaded the anti-poaching policy in Balule (see further), which is why participant observation took place at this region.

To evaluate the Balule conservation, this case study combined participatory observation and interviews, which allowed the gaining of context-specific insights (Yin 2009). Six weeks of field research provided the opportunity to directly observe and participate in the Balule conservation model on a day-to-day basis. Moreover, 28 interviews were conducted with people directly involved in this collaborative multi-stakeholder initiative. The interviews intended to identify 
perceptions of risk and challenges for stakeholders in their respective area, examine what measures are employed, and determine whether and how they respond to situational needs. These respondents were selected through purposeful sampling. Table 1 provides an overview of the respondents and their expertise. The semi-structured interviews were tailored to the respective stakeholders. The respondents gave informed consent for their information and names to be included in this study. The interviews by the Armed Response and Tactical Unit as well as the Black Mamba APU were handled confidentially. The interview data was crossreferenced with field notes and documents collected throughout the six-week participatory observation.

Table 1: List of Respondents

\begin{tabular}{|c|c|c|c|}
\hline Respondent & Organization & Experience or function & Interview date(s) \\
\hline Tom Tochterman & Rhino Mercy & $\begin{array}{l}\text { CEO of Rhino Mercy, Researcher, and } \\
\text { PhD Candidate in Environmental } \\
\text { Leadership }\end{array}$ & $\begin{array}{l}\text { January } 16 \& 30, \\
\text { 2014; February 6, } \\
\text { 2014; March 2, 2014 }\end{array}$ \\
\hline Craig Spencer & $\begin{array}{l}\text { Balule Nature } \\
\text { Reserve -Olifants } \\
\text { West (OWNR) }\end{array}$ & $\begin{array}{l}\text { Head Warden Balule Nature Reserve } \\
\text { and Warden Olifants West Nature } \\
\text { Reserve, Researcher and Lecturer of } \\
\text { Conservation and Ecology, Wildlife- } \\
\text { Anti-poaching Police background }\end{array}$ & $\begin{array}{l}\text { January } 17 \& 24, \\
\text { 2014; February 20, } \\
\text { 2014; March 3, 2014 }\end{array}$ \\
\hline Stefan Bosman & $\begin{array}{l}\text { Balule Nature } \\
\text { Reserve-Olifant } \\
\text { West (OWNR) }\end{array}$ & $\begin{array}{l}\text { Assistant Warden Olifants West } \\
\text { Nature Reserve and Coordinator } \\
\text { Rhino Monitoring }\end{array}$ & $\begin{array}{l}\text { January } 18 \& 31 \\
2014 ; \text { February } 24, \\
2014\end{array}$ \\
\hline Cornell Vermaak & $\begin{array}{l}\text { Balule Nature } \\
\text { Reserve-Parson } \\
\text { (PNR) }\end{array}$ & Warden of Parsons Nature Reserve & January 27,2014 \\
\hline Rian Ahlers & $\begin{array}{l}\text { Balule Nature } \\
\text { Reserve - Joint } \\
\text { Operation Center } \\
\text { (YNR) }\end{array}$ & $\begin{array}{l}\text { Chief of JOC and Warden of York } \\
\text { Nature Reserve }\end{array}$ & $\begin{array}{l}\text { February } 13 \& 27 \\
2014\end{array}$ \\
\hline Staff & $\begin{array}{l}\text { Black Mamba Anti- } \\
\text { Poaching Unit (APU) }\end{array}$ & Day to Day Anti-poaching Operations & $\begin{array}{l}\text { January 22, 2014; } \\
\text { February } 12 \& 28 \\
2014\end{array}$ \\
\hline Staff & $\begin{array}{l}\text { Armed Response } \\
\text { and Tactical Unit }\end{array}$ & Security and Anti-Poaching & $\begin{array}{l}\text { January 23, 2014; } \\
\text { March 1, 2014 }\end{array}$ \\
\hline Vincent Barkas & Pro-Track & $\begin{array}{l}\text { Security Operations, CEO of Pro-Track, } \\
23 \text { years of anti-poaching experience }\end{array}$ & $\begin{array}{l}\text { January 20, 2014; } \\
\text { February 5, } 2014\end{array}$ \\
\hline Staff & Pro-Track & $\begin{array}{l}\text { Military background, day to day anti- } \\
\text { poaching operations }\end{array}$ & $\begin{array}{l}\text { January 18, 2014; } \\
\text { February 26, } 2014\end{array}$ \\
\hline Coert Joordan & SANParks-Lawyer & $\begin{array}{l}\text { Legal Counsel for SANParks, mainly in } \\
\text { Poaching trials }\end{array}$ & January 31, 2014 \\
\hline Allison Thomson & $\begin{array}{l}\text { Outraged South } \\
\text { African Citizens } \\
\text { Against Poaching } \\
\text { (OSCAP) }\end{array}$ & OSCAP spokeswoman & February 3, 2014 \\
\hline Kirsty Brebner & $\begin{array}{l}\text { Endangered } \\
\text { Wildlife Trust } \\
(\text { EWT) }\end{array}$ & Rhino Project Manager & February 4, 2014 \\
\hline Dr. Lorinda Hern & Rhino Rescue & Lecturer at University of Pretoria and & February 5, 2014 \\
\hline
\end{tabular}




\begin{tabular}{|l|l|l|l|}
\hline & Program (RRP) & $\begin{array}{l}\text { Founder of Rhino Rescue Project and } \\
\text { Rhino\&Lion Reserve }\end{array}$ & \\
\hline Lauren Saad & $\begin{array}{l}\text { Ezulwini Game } \\
\text { Lodges }\end{array}$ & $\begin{array}{l}\text { Tourism Entrepreneur and Lodge } \\
\text { Manager }\end{array}$ & February 15, 2014 \\
\hline
\end{tabular}

This study did not aim to show whether the employed measures were effective because they have not been in place from a sufficiently long time. However, our analysis indicates the measures that appear to be more promising than others. For confidentiality and precaution, we do not reveal data about Balule's rhino population, manpower, deployment, picket sites, and tactical setups. Revealing such information would not only breach confidentiality but also jeopardize the success of the program. The findings of this case study are specific to Balule Nature Reserve. The spatial conditions for this reserve are unique, but similarly to other contexts, poaching threats and counter-measures may change. With mindfulness of these limitations, our findings still allow reflection on anti-poaching and conservation in other settings.

\section{Findings on the Etiology of Rhino-poaching}

In what follows, we discuss findings regarding the etiology of rhino poaching, using the criteria of routine activity, rational choice, and situational crime prevention theories.

\section{1. $\quad$ Rhinos and Routine Activities}

In line with routine activity theory, we assess the suitability of rhinos as a target based on four criteria: visibility, accessibility, value, and inertia (Cohen \& Felson 1979).

The visibility depends on the size of the property and the size of the population: ten rhinos are much less likely to be visible on a reserve of 25,000 hectares than on a small game farm of 250 hectares. The habitat also impacts the visibility: while African white rhinos are grazers, inhabiting lower plains and grassy savannahs, African black rhinos are browsers and prefer wooded, rocky mountain terrains. This makes the white rhino easier to spot. Other determining factors are the location of the reserve, the presence of communities within the reserve, the rhino population density, the number of water sources on the reserve, and the regularity of animal migration to these water sources.

Accessibility is both factual and perceived. At present, private game reserves are usually guarded, yet widely accessible to the public. Their purpose is to stay connected to their surroundings. Lodge operators, tourists, building and maintenance contractors, and family and friends of personnel on the reserve generally have access to Balule and thus access to the animals as well. This is further increased with self-drive safaris, because potential offenders engage in reconnaissance before actually committing poaching crimes. The scouting of a 
potentially suitable target may very well happen during the day and through legal access to a reserve. Accessibility is closely connected to guardianship or lack thereof, once again both factual and perceived (Cohen \& Felson 1979). Guardians are not solely governmental actors, but can be anyone. It is in the interest of reserves to extend their guardianship as much as possible to prevent poaching. Technology and improved training regimes can enhance guardian capabilities tremendously and can ease the workload of existing guardians. Accessibility also refers to the number of game drives and anti-poaching unit patrols, as well as animal migration to waterholes as routinely occurring activities that can be used by poachers to plan crime. In sum, rhinos are very accessible in the current poaching crisis, either through legal or illegal means.

A black market rhino horn is priced at EUR 50,000 or USD 56,000 per kilogram (Rhinomercy, 2014). The inertia of rhino horns as a target is fairly low due to the fact that, at an average weight of $4 \mathrm{~kg}$ and average seize of 50 to $90 \mathrm{~cm}$ per horn, they are easily concealed and transported (The International Rhino Foundation, 2010).

Routine activity theory helps explain rhino poaching. Offender motivation may be hard to assess or influence, but target suitability and the absence of capable guardians are more malleable. This does not mean that rhino poaching can be designed out of its environment entirely, but rather that the numbers of perceived opportunities for this crime may be reduced.

\subsection{Rhinos and Rational Choices}

In line with rational choice theory, we analyzed offenders' cost-benefit analyses of perceived risk, anticipated effort, and potential reward of rhino poaching (Cornish \& Clarke, 1986, 2003). The anticipated effort can be found in the time needed to plan, prepare, and perform the crime. Time and money are both required to gain access to weapons, a vehicle, and other equipment, the time needed to locate a rhino, the actual time the offender will have to spend on foot in a reserve, and endure hardships before and after the crime. Anticipated effort also entails gaining access to a reserve and exiting it with the rhino horn by legal or illegal means (e.g., climbing or cutting a fence). The resources, time, and energy invested in gathering intelligence, information, and skills (shooting a weapon, tracking animals, survival in harsh conditions, decoy techniques) needed to perform the crime count as well.

Perceived risk is the second element. A potential offender performs reconnaissance and adjusts his risk perception accordingly. When the risk is perceived too high, the potential offender may be deterred, switching to a less-risky crime or to a softer target (e.g., a less guarded area). Intrinsic risk factors (risk of physical harm) vary for each reserve and depend on the amount of 
visible guardianship (manpower), barriers (fence or wall), technology, potentially dangerous animals, and reserve size. Extrinsic risk factors (risks of legal repercussions) are the certainty, severity, as well as the swiftness of punishment, the legal classification (misdemeanor or felony) of the act, and whether it is perceived as immoral by society. For rhino poaching and other environmental crimes, the perceived risk with regard to certainty, severity, and celerity of punishment is low (Faure, 2009). It is only in recent years that offenders have occasionally received substantial jail time (Rademeyer, 2012). Respondent Coert Joordan assessed that "only $20 \%$ of poaching dockets result in trials, because of faulty paperwork, lacking chain of custody and an overburdened court system." Public shame is also limited as the widely-publicized rhino poaching trial against the Dawie Groenewald gang is still pending, despite the arrest dating back to September 2010 (Financial Transparency Coalition, 2013). Moreover, rhino poaching is often classified as a less serious offense with pre-trial bail creating the perception that rhino poaching is permissible. Respondent Kirsty Brebner confirmed that "certain parts of South African society see a rhino as "just an animal," especially in contrast with other forms of crimes that are rampant."

The third and last element is expected reward, which can be very different from the actual reward received, especially for first-time offenders. Repeat offenders can anticipate this better and might look for markets prior to committing their crimes. This perceived reward is the money they expect to receive and how that will make it possible to buy things they could otherwise never achieve through legal means. Arrests in Balule have made clear that low-level poaching groups can earn up to 360,000 ZAR (approximately EUR 23,000 or USD 26,000) for each horn ( $4 \mathrm{~kg}$ ), for a group of 4 or 5 poachers. Putting it into perspective, this means that each poacher earns over four times the annual income of a domestic worker. The expected reward is also influenced by how rare the horn is. With rhinos on the brink of extinction, rhino horn is likely to become more valuable.

\section{Findings on the Balule Rhino Conservation Model}

In what follows, we assess the governance characteristics of our case. First, the sociopolitical context is discussed. Next, the organization and management of the Balule Rhino Conservation Model multi-stakeholder framework is analyzed. The article continues by discussing the measures in place at Balule Nature Reserve to counter rhino poaching. The measures employed at the site of research for this study will be classified within the table of situational crime prevention measures (Table 2).

\subsection{Sociopolitical Context}


In 2011, the Balule Rhino Conservation Model was developed to counter the anticipated displacement of poaching incidents from Kruger National Park, which had increased security. This was further influenced by the introduction of a population of black rhinos to Balule Nature Reserve as part of the Black Rhino Range Expansion Project (BRREP) of the World Wildlife Fund (WWF). This project aims to increase the black rhino population through the creation of new populations (World Wildlife Fund, n.d.). Since September 2013, the Balule Rhino Conservation Model has been fully operational in the Olifants West region of the reserve.

The Balule Model is a unique type of public-private partnership for South Africa because it involves governmental stakeholders as well as domestic and international non-governmental organizations, non-profit organizations, and private security stakeholders. Its uniqueness lies also in its ambition to change the existing socioeconomic disparities within the local community, in addition to threat response measures and anti-poaching efforts. The Balule governance model aims to create social change and community involvement, because effective long-term wildlife protection requires local communities experiencing the benefits of wildlife. The model generates local ownership and job opportunities for formerly disadvantaged communities, creating a vested interest in the survival of wildlife in general and rhinos in particular.

Despite South Africa being among the most prosperous African democracies, its sociopolitical and economic situation is one where white people enjoy the majority of wealth, while most black people live in poverty (Conway-Smith, 2014). Respondent Vincent Barkas explains this fact as follows: "[S]ince colonial times, wildlife and nature reserves as well as hunting concessions have been regarded as 'the white man's playground and toys'." This comment illustrates the remaining cultural divide. The average person from an indigenous community has never been able to enjoy wildlife, much less benefit from its existence, other than for food (Bracken \& Barkas, 2013). The environmental monitors employed in the Black Mamba Anti-Poaching Unit (see below) have also supported this claim during their interviews: "[W]e never had the opportunity to view, photograph or experience wildlife prior to working for [the] Balule [Rhino Conservation Model]. In collaboration with the Kruger2Canyon Biosphere, SANParks, and the National Department of Environmental Affairs (K2C Environmental Monitors 2013), the Balule Rhino Conservation Model not only recruits Environmental Monitors from local disadvantaged populations, but also establishes initiatives such as Green Kidz to directly involve local children in wildlife conservation activities, spark their interest, and educate them about the importance of conservation" (Brassett, 2014). Their Environmental Monitors are also sent out to local schools and villages as Wildlife Ambassadors, thereby creating new learning opportunities. Moreover, in collaboration with lodges and tourism providers on the reserve, they invite local 
schoolchildren on game drives, bush walks, wildlife activities and even rhino collaring, providing them with unforgettable experiences.

\subsection{Poaching Risk Assessment for Balule Nature Reserve}

The western and northern boundaries of Balule Game Reserve are marked by a fence of 25 kilometers with different access gates. This fence stands next to Route 40, a tar road between Hoedspruit and Phalaborwa with heavy mining traffic. The fence is mainly designed to keep animals in, not to keep people out. From the road, poachers might spot animals or look for weaknesses in the fence. The eastern boundary is completely unfenced and game migrates in and out of the area according to their needs. In the south, Balule is bordered by Tshukudu Game Reserve and separated from it with a fence.

Interviewee Rhian Ahlers explained that "the Olifants River and a railroad line [towards the mines] intersect the reserve and both are known to be used as points of entry for poachers." Suspected poachers are nearly impossible to track as they can easily mask their spoor both in the river and on railroad tracks. Trains transport cargo only, but at certain points they are slow enough for a person to jump on.

Hoedspruit is the closest town. It has about 3500 inhabitants, a high unemployment rate (40 per cent), persisting poverty, and 21 per cent of people over 20 years have no education (Yes! Media, 2012). A small number of indigenous people live on Balule Nature Reserve land and some of them work for lodges or private landowners. Some indigenous people employed on the reserve have set snares and cages, which threaten all wildlife due to their indiscriminate nature. Respondent Craig Spencer assessed that "sustenance poachers never know nor care which animal is caught." Vincent Barkas added that "bush meat harvesting happens both because of local tradition and tribal culture, and for sustenance given the poverty and unemployment, despite [the fact] that the reserve is not considered tribal land and is not contested as such."

Another risk element is the availability of firearms. Although these are generally stored at every game lodge and farm, the control of weapons is fairly lenient and every game ranger has access. "Local farms outside of the reserve have also been robbed for their firearms (hunting rifles), which often reappear in poaching incidents," according to interviewee Craig Spencer. Moreover, guests can bring weapons to the reserve if they comply with South African legislation and have a valid permit.

\subsection{Organizational Model}

The Balule Rhino Conservation Model is organized as a pyramid, as represented in Figure 2. 


\section{Figure 2: Balule Rhino Conservation Model}

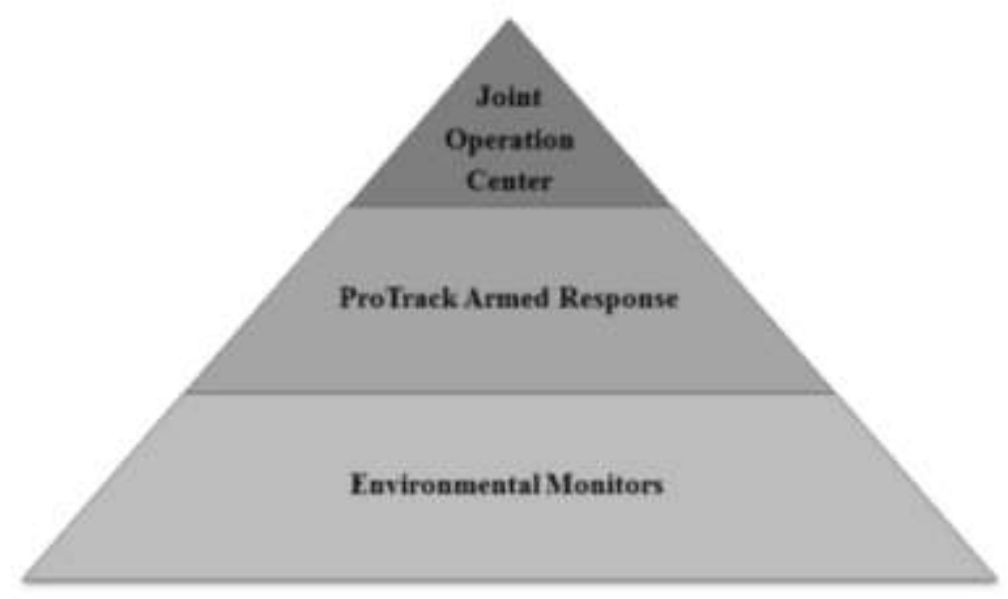

The Environmental Monitors play an integral role as visible patrols and "boots on the ground" within the reserve. This was initially meant to create jobs for disadvantaged groups and had the additional benefit of addressing poaching and other environmental threats (K2C Environmental Monitors 2013). Environmental Monitors are included in the overall anti-poaching strategy and are mainly young women. By offering disadvantaged communities prestigious employment in an industry they historically never had access to, they earn a sustainable income, build a skill set through accredited training, and can expect to receive more responsibility in the future. Craig Spencer explained that "the standard training is in hand-to-hand combat, search and seizure, arrest and court procedures, creation of statements and dockets, handling and chain of custody of evidence, road blocks and gate operations, legislation, snake handling, alien vegetation removal, snare detection and removal, weapons handling, safety and certification." This results in gaining security clearance. It is hoped that employing women will lead to their appreciation for wildlife and conservation being passed down to their children. Albeit a long-term goal, changing perceptions about wildlife are an integral part of the governance model. The government's initial plan proposed 1000 environmental monitors to be trained and paid by SANparks (South African Department of Environmental Affairs, 2014). Within Balule, the aim is to increase the number of Environmental Monitors to one per 1000 acres, but currently only Olifants West Region has them, represented by the Black Mamba Anti-Poaching Unit. The Black Mambas initially consisted of four females and three males, all of whom were formerly unemployed, but now on average sustain six people as sole breadwinners. They work on 21 day rotating schedule, receiving room, board, and apparel in staff compounds on the reserve and ten days of leave, spent in their home communities. Recently, the Black Mambas received national and international attention and recognition for their work. They were distinguished with the 
South African Best Conservation Practitioner Award ${ }^{4}$ and the United Nations Environmental Program's Champions of the Earth award5.

The second level of the pyramid is the Pro Track Armed Response Team, which responds to detections from the Environmental Monitors and to other intelligence concerning poaching and incursion threats. Created in 1992, this was the first private anti-poaching unit in South Africa and is currently the largest (Pro Track, 2011). This team lives in very basic accommodation and is permanently located within the reserve on a rotational basis to reduce incident response time. Vincent Barkas claims that, “[i]n line with Pro-Track's socially responsible vision, training and work happens in groups of mixed ethnicity, which is a change from the norm. Especially for black people this qualified training program is a possibility for upward development they seldom have access to." Contrary to Kruger NP and many law enforcement and even conservation agencies, where the success rate of operations is often measured by how many poachers are shot, Pro Track believes a shoot to kill policy brings more harm than good. "Every time you shoot a poacher, you take away a provider from a community and, therefore, antagonize the rest of that very same community, due to shooting one of their own," Vincent Barkas stated. It is also illegal for private security employees to use lethal force for suspected poachers, unless facing a threat to their life. Also, for every casualty, several others are willing to fill in, given the monetary rewards. Moreover, use of lethal force voids the possibility of intelligence gathering at the source to find the middlemen within poaching syndicates. This does not always work, because, similarly to international wildlife trafficking syndicates, poachers on the ground engage in division of labor and knowledge and have become more organized and sophisticated in recent years.

The Joint Operation Center is at the top of the pyramid and serves the entire reserve. This twoperson team coordinates all operations, collaborates with neighboring reserves' anti-poaching coalitions, and collects, evaluates, and disseminates outside intelligence about poaching threats. They also manage the intelligence network of informants and independently investigate reported poaching threats outside of the reserve's borders. It is a regional center of expertise to counter poaching threats (Rhino Mercy, 2013). Their main challenge is incident response time, given the absence of (expensive) air support, and surveillance (e.g., drones) to direct ground troops to suspected poachers.

\subsection{Situational prevention measures at Balule}

$4 \quad$ http://www.hi-tec.com/uk/blog/black-mambas-win-best-conservation-practitioner-at-the-rhinoconservation-awards.html

${ }^{5}$ http://web.unep.org/champions/laureates/2015/black-mamba-apu 
The Balule Rhino Conservation Model employs reactive and proactive threat response measures and measures to safeguard the integrity of the program and its employees. We discuss each of these measures and provide a summary table at the end of this section.

The first reactive measure is hotspot and buffer zone patrol. Green intelligence (referring to range and terrain preferences of rhinos) combined with red intelligence (referring to the analysis of intrusions' port of entry and distance traveled) allows the identification of hotspots where the location of assets, reserve weaknesses, and (unknown) intruders converge. This is in line with routine activity theory. Rian Ahlers explained that in Balule, "two types of hotspots exist: poaching hotspots where the threatened animal is located and intrusion hotspots due to vulnerabilities of the location itself." These hotspots need increased management and control, although available resources currently do not allow covering all hotspots. To relieve some poaching pressure for the reserve, a 24-hour standby tactical unit of Pro Track responds to threats inside and outside the reserve's boundaries. This creates buffer zones and drives threats further away or intercepts them before reaching the reserve. Hotspot patrolling and buffer zone patrolling, both intelligence-led policing strategies, are ways to supply formal surveillance geared toward situations on the ground (Clarke, 1997, p. 18).

The second reactive measure is Environmental Monitors (Black Mamba Anti-Poaching Unit), who serve both as a visual policing component and a patrol within the reserve. They patrol the fence and buffer zone, assist in gate operations and roadblocks, remove snares and alien vegetation, and relay all gathered information to their commanding officer. This is a measure of surveillance through employees (Clarke, 1997) and extending the guardianship (Cohen \& Felson, 1979) of the reserve. UNEP reported that the presence and operations of Black Mambas had reduced snaring by 75\%, made poaching numbers plummet, and led to several arrests. Furthermore, UNEP mentioned community empowerment and environmental education as reasons they received the award.

The third reactive measure is the support of a $\mathbf{K 9}$ unit within Black Mambas. The four-year-old Belgian Malinois Shaya is trained to detect weapons, ammunition, ivory, and rhino horn. He assists with crime scene processing and gate operations on a regular basis and is dispatched to neighboring properties for assistance. Shaya was trained in Germany by the non-profit Rettet das Nashorn and the Hessen police and later donated to the Balule Nature Reserve. His handler, Craig Spencer, proudly shared that "Shaya's record so far consists of the successful detection of eight weapons, 112 rounds of ammunition and a variety of other poaching equipment, like machetes and silencers." His presence at the gates serves as a natural deterrent for potential offenders. The use of a detection dog serves a dual purpose in situational prevention: simplifying 
control by detecting poaching facilitators, such as weapons and ammo, and removing crime benefits by detecting rhino horn and ivory before both leave the reserve, leading to judicial proceedings and possibly punishment.

The first proactive measure is VHF (using radio frequency) and GPS (using satellites) collaring, which is used to follow rhinos (e.g., through GIS mapping). This green intelligence is a conservation monitor and anti-poaching measure, providing information on habitat use, range and terrain preferences and allowing anti-poaching entities to locate assets in the field, anticipate hot spots, and deploy their forces accordingly. GPS collars send an alarm when it is immobile for a longer period, i.e., when either the collar is lost or an animal is sick, dead, or killed. GPS collars are also used as a geofence, meaning that an alarm is sent as soon as animals cross a set boundary (e.g., a hot spot). Collaring requires immobilization, but other tests such as blood samples, parasite checks, ear notches for identification, pregnancy test, and health and welfare assessment are performed at the same time.

The second proactive measure is motion-triggered camera traps, which are placed on waterholes, roads, and others. These traps transmit pictures to cellphones of the chief of the Joint Operations Center, the warden, and the assistant warden of the respective section. This is also a conservation monitor (waterhole use, migration) and remote anti-poaching measure. Threat response can be immediate, conditional on cellphone coverage, and happens without perpetrators' knowledge. Response time is an issue because of the vast territory.

The third proactive measure is the rhino horn alteration in the form of (pink) dye infusion (Rhino Rescue Project 2012). Balule Nature Reserve was the first to treat their population of rhinos using this method when it became available in 2011. In this method, a microchip is inserted into the horn, which allows tracking a rhino for the growth period of the horn (3-4 years). The rhino is immobilized for $45 \mathrm{~min}$, but at the same time, a DNA sample is taken for the national Rhodis database. Rhino horn alteration requires warning signs (in Chinese, English, Tsonga, and Zulu) about the treatment and its adverse effects. Critics think that this can lead poachers to shoot another rhino when they discover the pink horn of their previous kill. Others refer to the possible displacement and the poisoning of rhino horn consumers (Rhino Rescue Project 2012). In combination with other measures, rhino horn alteration is still a very visible form of policing. Lorinda Hern explained that currently "other horn alteration methods are explored such as radioactive isotopes, which would allow detection in airport scanners and sends a strong message to local poachers, but comes with health risks for humans, not for the rhinos." 
The fourth proactive measure is fence and gate operations. A large portion of Balule's borders is fenceless, but the western boundary along Route 40 (about 25 kilometers) is controlled by registering details of people who drive into the reserve and performing a thorough check of all vehicles leaving the reserve (guests, contractors, lodge personnel, landowners, and so on). Selfdrive for guests is allowed, which provides opportunities for illegal activities. Day and night, there are regular fence patrols and random checks of vehicles inside the reserve.

The fifth proactive measure is that because some locals (e.g., lodge staff) set snares and (sustenance) poach, a database of all employees on the reserve was created, which led to identification cards to be shown at the gate. This allows assessing how many people are employed on reserve grounds and where their home communities are. The intelligence network uses the database and social media to identify possible high-threat personnel, not for rhino poaching as such but for selling information about rhinos' whereabouts.

The sixth proactive measure is Research and education. The Research and Voluntourism Camp of TransFrontier Africa, a non-profit organization, provides basic accommodation, research, and education opportunities for ecologists, conservationists, biologists, and more recently, criminologists. The camp also houses the so-called "voluntourists," interested tourists who stay at the camp to learn about rhino conservation and anti-poaching while living in a "big 5" environment in an unfenced camp with only solar power. The goal is to raise awareness and required funds.

Finally, the Armed Response Unit within the reserve has adopted some proactive measures to address vulnerabilities presented by the lay of the land. Solar lights are installed on trees near ports of entry along the river and railway. Vincent Barkas elaborated on a more creative measure in which "helium balloons with glow sticks are released so that poachers may mistake them for air support or drones and may desists from entering the reserve." Moreover, decoy rhinos are placed at poaching hot spots, and these hot spots are surrounded by camouflaged Armed Response Units who quickly arrest those who shoot at the decoys. Poachers may not be able to distinguish live rhinos from decoys, especially at night.

The Balule Rhino Conservation Model encompasses various integrity measures, in addition to the abovementioned proactive and threat response measures. There is mandatory polygraph testing for all employees involved in an anti-poaching unit, serving both to identify possible poacher informants and safeguard against outside allegations of criminal activities by personnel. Failing the test or not attending two polygraph appointments can lead to reassignment or dismissal. Environmental Monitors carry a GPS tracker during patrols to mark animal, snare, and alien vegetation locations and track their patrol route. Carrying this GPS tracker takes away 
potential suspicion about involvement in poaching activity and holds them accountable. The Armed Response Unit and Tactical Unit have radios; thus, the Joint Operations Center can track them and listen-in remotely. Rian Ahlers explained that "this is [first and] foremost a safety measure for high-threat situations, but can also be used to randomly listen to conversations to detect possible poaching information exchange." Information on patrols and picket sites is relayed on a short notice to anti-poaching unit members to ensure that they do not warn poachers. Only team leaders have access to green intelligence to coordinate patrols. These integrity measures are situational prevention techniques employed to reduce temptation to pass on information to poachers, who may then lack the necessary information to determine risks, efforts, and rewards and desist from targeting the location where they are applied.

As presented in Table 1, Clarke's (1997) original table of situational crime prevention techniques is supplemented with the respective proactive, reactive, and integrity measures at Balule. Measures that are not in use for ecological reasons (e.g., dehorning) or not (yet) in use for financial reasons (e.g., drone surveillance) appear in italics.

Table 2: Summary of Situational Prevention Techniques

\begin{tabular}{|c|c|c|c|}
\hline Increasing Perceived Effort & Increasing Perceived Risks & $\begin{array}{c}\text { Reducing Anticipated } \\
\text { Rewards }\end{array}$ & Removing Excuses \\
\hline $\begin{array}{l}\text { 1. Target hardening } \\
\text { Rhino collaring } \\
\text { Intelligence-led patrols } \\
\text { Reducing target visibility } \\
\text { from outside a reserve }\end{array}$ & $\begin{array}{c}\text { 5. Entry/exit screening } \\
\text { Gate operations } \\
\text { Search procedures for } \\
\text { vehicles, persons, personal } \\
\text { items, and luggage } \\
\text { ID of contractors \& service } \\
\text { providers }\end{array}$ & $\begin{array}{l}\text { 9. Target removal } \\
\text { De-horning } \\
\text { Translocation }\end{array}$ & $\begin{array}{c}\text { 13. Rule setting } \\
\text { Signage of reserve rules at } \\
\text { gates } \\
\text { Signage of legal obligations } \\
\text { concerning poaching at gates }\end{array}$ \\
\hline $\begin{array}{l}\text { 2. Access control } \\
\text { Entry and Exit screening } \\
\text { Identification of persons } \\
\text { entering and exiting } \\
\text { Visible \& maintained fence } \\
\text { Employee database }\end{array}$ & $\begin{array}{c}\text { 6. Formal surveillance } \\
\text { Pro-Track Armed Response } \\
\text { Teams } \\
\text { UAV/Drone Surveillance } \\
\text { Air Support by Helicopter } \\
\text { and/or light Aircraft }\end{array}$ & $\begin{array}{l}\text { 10. Identifying property } \\
\text { Horn infusions } \\
\text { Micro-chipping horn } \\
\text { Rhino collaring } \\
\text { Ear-notching rhinos } \\
\text { Signage at fence-line and at } \\
\text { other ports of entry }\end{array}$ & $\begin{array}{l}\text { 14. Stimulating conscience } \\
\text { Repeated warning signage } \\
\text { Spreading Awareness among } \\
\text { visitors, clients \& employees } \\
\text { Radio/TV adverts to raise } \\
\text { awareness }\end{array}$ \\
\hline $\begin{array}{c}\text { 3. Deflecting offenders } \\
\text { Visible policing } \\
\text { Fence patrols } \\
\text { Posting of warning signs } \\
\text { Randomizing patrol routes \& } \\
\text { times } \\
\text { Extensive Ecological } \\
\text { Management/ "Sanctuary in a } \\
\text { Sanctuary" }\end{array}$ & $\begin{array}{c}\text { 7. Surveillance by employees } \\
\text { Black Mamba Anti-Poaching } \\
\text { Unit } \\
\text { Warden Team } \\
\text { Ad-hoc stop and search of } \\
\text { vehicles on the reserve } \\
\text { Reporting of } \\
\text { vehicles/persons by game } \\
\text { drives over radio } \\
\text { communication }\end{array}$ & $\begin{array}{c}\text { 11. Reducing temptation } \\
\text { Signage along fence } \\
\text { Horn infusions } \\
\text { Rotational assignment of } \\
\text { Armed Response team } \\
\text { Short-notice deployment to } \\
\text { picket sites } \\
\text { GPS-traceable radios for } \\
\text { patrols } \\
\text { Polygraph testing of } \\
\text { employees \& security } \\
\text { providers }\end{array}$ & $\begin{array}{l}\text { 15. Creating Inhibitors } \\
\frac{\text { (formerly: Controlling dis- }}{\text { inhibitors) }} \\
\text { Environmental education for } \\
\text { children and adults of local } \\
\text { communities } \\
\text { Creating vested interest by } \\
\text { employment/benefits } \\
\text { Whistleblower Program } \\
\text { (possibly with benefits for } \\
\text { information) }\end{array}$ \\
\hline
\end{tabular}




\begin{tabular}{|c|c|c|c|}
\hline & & Media Publications & \\
\hline $\begin{array}{c}\text { 4. Controlling facilitators } \\
\text { Detection dog } \\
\text { Gate operations } \\
\begin{array}{c}\text { Weapon Registration \& } \\
\text { Regulations }\end{array}\end{array}$ & $\begin{array}{c}\text { 8. Natural surveillance } \\
\text { Guests, lodge owners, } \\
\text { Tourism operators, general } \\
\text { public }\end{array}$ & $\begin{array}{c}\text { 12. Denying benefits } \\
\text { Detection dog } \\
\text { Horn infusions } \\
\text { Pertable GPS transmitters for } \\
\text { service provider vehicles } \\
\text { snares before collected } \\
\text { New methods of detection, i.e., } \\
\text { radioisotope marking }\end{array}$ & $\begin{array}{c}\text { Community work via Pro } \\
\text { Track } \\
\text { Green Kidz }\end{array}$ \\
\hline
\end{tabular}

\section{Discussion of strengths and weaknesses of the Balule Conservation Model}

The multi-stakeholder framework employed at Balule Nature Reserve has several strengths in countering poaching threats. First, it includes employees from local, disadvantaged communities, creating local ownership, lasting social development, and employment in an industry that women previously lacked access to. As one of the few initiatives in the region, it actively tries to create social change. Second, the three tiers of the network, while hierarchically organized and somewhat dependent on the flow of information among each other, work in a largely independent manner toward the common goal of securing the reserve against poaching threats. This safeguards the integrity of the model. Third, this framework is tailored to the situation and is very adaptable. Albeit sometimes limited by finances, it tackles the most imminent threats of poaching for the reserve. This would of course require updates as new needs and vulnerabilities arise.

This governance framework also faces challenges because it is very center-pivot, managementintensive, and financially strapping. It relies strongly on the leadership, devotion, motivation, capacities, and capabilities of the warden of the Olifants West Region. In addition to managing the anti-poaching initiative, this warden handles the detection dog and serves as a regional warden, managing all of the concerns and duties associated with this position. Furthermore, financially speaking, the framework as it is cannot be sustained indefinitely. Tom Tochterman explained that during "the first three years, the anti-poaching measures cost 1,140,000 ZAR [approximately EUR 74,000 or USD 82,000] in total, which was raised through charities, nonprofit organizations and international donors, [excluding] salaries, fuel, repair and maintenance costs." Donor fatigue may occur, and thus alternative income options and budget cuts are worth exploring. Some reserves sell rhinos or other large mammal species for hunting, but with dwindling populations this is not a viable option, especially given the potential public relations backlash. 
One of the biggest challenges for rhino conservation lies in law enforcement capabilities. As privately owned land, Balule Nature Reserve receives no governmental law enforcement support for policing or prosecution. Poaching incidents can be reported at any police station but are investigated by one sole unit: the Directorate for Priority Crime Investigation (DPCI), also called the Hawks. This group investigates corruption, organized crime, and money laundering (Corruption Watch South Africa, 2014). Rhino poaching has been given priority crime status and falls under the Hawks investigate obligations (Munusamy, 2013). As Craig Spencer notes, "The DPCI station closest to Balule is three hours away [in Polokwane], employing four officers." These officers, who each investigate an average of 100 rhino-related offenses per year, are far too few to follow-up every rhino poaching incident. Moreover, specific environmental courts no longer exist in South Africa. The green court in Hermanus (2003 to 2007) was established as a pilot project whose main purpose was to combat abalone poaching. It was very successful and had a conviction rate of $85 \%$, often without bail and with prison sentences. It also freed other courts from the high number of environmental cases (Gosling 2006). As Kirsty Brebner notes, "The court system is overburdened given the high crime rate and prosecutors and judges generally lack expertise on environmental crime and harm." Re-establishing an environmental court would match the high priority crime status of rhino poaching and might help to alter the risk perception of poachers.

\section{Recommendations for Improving Governance in Balule Nature Reserve and Other Anti-poaching Contexts}

The following recommendations are not meant to be exhaustive. We are aware that most depend on the presence of sufficient funding. However, we believe these are important to sustain and improve the governance model at Balule Nature Reserve.

To increase the surveillance capacities of the model, the existing measures could be supplemented by air support through a drone or lightweight aircraft. This would come with the distinct advantage of being able to better coordinate ground forces and reduce incident response time. To finance a drone, the idea of making it commercially beneficial to lodges and the reserve could be further explored. These entities could be asked to share in costs for purchase and maintenance. A drone could, while flying over the reserve, log animals spotted into a database. This database could be made available to contributing lodges to improve their game drive routes, which would then improve their own profile and attract more guests. Furthermore, a drone could aid in performing annual game counts on the reserve, and thereby reducing expenditures for helicopter fuel and airtime, as well as pilot remuneration. 
To reduce expenditures for the anti-poaching initiative, extensive ecological management could be implemented. Until South Africa finds a way to adequately prevent, enforce, and investigate rhino poaching, and until consumer demand reduction projects in Asia have taken effect and resulted in a credible threat reduction, a sanctuary-in-a-sanctuary ecological approach might be the most viable short- and mid-term solution. Rhinos currently traverse over 50,000 hectares of bush, which makes protection very difficult. With poaching numbers increasing, population numbers have fallen so much that finding a mate to reproduce is very unlikely in such a vast space. This extensive ecological management requires the use of green intelligence to determine the habitat range of the majority of the two rhino species in this reserve. If necessary and financially possible, it could mean the relocation of the rest of the populations into the proposed sanctuary. The benefit of the sanctuary-in-a-sanctuary method is a higher likelihood of reproduction. The smaller fenced area would also the decrease the management and personnel required to protect the rhinos. At the moment, patrol efforts are spread out over all of the reserve, whereas the sanctuary-in-a-sanctuary approach means definite knowledge of where the protected assets are, a shortened response time, and higher chances of arrest, should an offender nevertheless decide to try. Overall, this strategy would definitely aid in tilting the costbenefit equation of potential offenders toward a disadvantageous outcome. We realize that this is a radical ecological intervention, but it may be required to resurrect species numbers from near-extinction. This brought the white rhino back from near-extinction in the 1960s (Save the Rhino, 2015). One disadvantage of this approach is that rhinos would be less commercially available and visible for tourism providers in the reserve. However, this could easily be justified and explained to incoming guests, and the lodges' support for this measure could reinforce their claim of engaging in conservation efforts.

Other situational prevention measures can also increase the factors of anticipated effort, perceived risk, and expected reward for potential offenders. To increase guardianship, TransFrontier Africa can offer environmental education days for guest visitors living in lodges on the reserve, allowing them to gain knowledge of the Balule Rhino Conservation Model. Lauren Saad (Ezulwini Lodges), in her interview, highlighted the fact that "most of the clientele coming into the reserve do not have adequate knowledge that there is a poaching crisis in South Africa." Educating visitors would increase awareness about the rhino poaching problem and warn them not to buy trinkets made of endangered animal products. It would also improve TransFrontier Africa's profile as a provider of environmental education and provide income for the Balule Rhino Conservation Model.

The regime of publishing non-sensitive information on the Balule Rhino Conservation Model through various media channels is currently in place and should be continued. Moreover, other 
anti-poaching initiatives might benefit from implementing this regime because it raises awareness about rhino poaching and the non-suitability of the reserve for offending. The result is a perception of very high risk and effort.

The creation of a whistleblower program might also be useful for Balule and other anti-poaching contexts. The creation of the program requires sufficient resources for its organization as well as for managing and verifying the information received. In addition, it might be useful to offer rewards to people who provide information about offenders and planned offenses. Although this would require additional money and time, the gathered information is likely to benefit intelligence-led policing in the reserve.

Another situational crime prevention measure that Balule Nature Reserve itself could consider pursuing is the mandatory outfitting of contractors and delivery vehicles with portable GPS transmitters. This would decrease the inherent risk these actors pose to the reserve's security profile.

Furthermore, the signs at the ports of entry could be improved, by outlining the regulations applicable to poaching. This would inform all incoming persons of obligations, aiding in removing excuses and the permissibility of the offense.

Lastly, if legally feasible, denying visitors the right to bring weapons into the reserve would aid in controlling facilitators of rhino poaching. At the very least, reserves could consider mandatory declaration and registration of weapons at entry gates.

\section{Conclusion}

This case study of the Balule Rhino Conservation Model aimed to improve our understanding of the crime of rhino poaching in this location, and analyzed whether and how situational prevention measures can alter the cost-benefit equation for potential offenders. It also considered how the sociopolitical and economic context affects both the crime itself and its governance.

In the larger scheme of transnational environmental crime, this initiative is buying time in the factual absence of governmental regulation and enforcement. The initiative is saving rhinos. On the other hand, South Africa is contemplating legalizing rhino horn sales in an attempt to outdesign the crime and avoid proceeds of wildlife crime by financing other international crimes such as terrorism (Foley, 2013; Kuhumbu \& Halliday, 2014). The size of public and private stockpiles is unknown, as is the demand for rhino horn. Some say that the proceeds of stockpile sales will benefit wildlife conservation, whereas others say that it will increase demand, as it did 
for the legalization of ivory (Endangered Wildlife Trust, 2013; Traffic 2013). By considering the fact that South Africa, at present, largely fails to sufficiently regulate existing domestic trade options, the suggestion of a highly regulated legal international trade scheme appears neither promising nor realistic.

While we examined the situational make-up of anticipated effort, perceived risk, and expected reward as well as the intricacies of the crime of rhino poaching, we realize that the anti-poaching initiatives have to try and impact various fronts at once. Legislative shortcomings seem to be adding to the low-risk perception of potential offenders. The lack of visible law enforcement efforts around and in private nature reserves is increasing the perception of a relatively low level of effort required to commit crime. The fact that the demand for rhino horn persists fuels the anticipation of a high reward. These are problems that one anti-poaching initiative alone cannot combat. Common sense informed the Balule Rhino Conservation Model about which measures to put in place to change the equation of risk, effort, and reward for the offender, inadvertently answering to the situational crime prevention theory. In essence, they intended to make this reserve the most undesirable, miserable place for potential offenders, and dissuade them from offending at this location without employing a general shoot-to-kill policy. Future studies should examine whether and how the measures should change over time.

Most importantly, these situational measures, i.e., reactive and proactive, are embedded within a conservation model that explicitly aims to change the social and cultural context. As a multifaceted conservation model, it provides research opportunities for various disciplines such as criminology, sociology, governance, law, tourism and hospitality studies, conservation, and ecology. Employing women from disadvantaged communities increases guardian capacities of the reserve. This offers a stable income from wildlife conservation, creates an opportunity for education, and fosters structural and cultural change.

\section{References}

Ammann, K. (2013, November 29). Of tiger and lion bones and the legalizing of the rhino horn trade. National Geographic.

Animal Rights Africa. (2009). Under siege: rhinoceroses in South Africa. Retrieved from http://www.rhinoresourcecenter.com/pdf files/125/1255419687.pdf

Artz, M. (2014). The Rhodesian bush war. Retrieved from https://mattartzblog.wordpress.com/tag/south-africa/

Baral, A. N. (2013). Impacts of wildlife tourism on poaching of Greater One-horned Rhinoceros (Rhinoceros Unicornis) in Chitwan National Park, Nepal. Retrieved from Lincoln University, New Zealand: http://researcharchive.lincoln.ac.nz/bitstream/10182/5273/6/Baral \%20mapplsc.pdf 
Beirne, P. (2013). Animal Rights, Animal Abuse and Green Criminology. In P. Beirne, \& N. South (Eds.), Issues in Green Criminology (pp. 55-86). New York City, New York: Routledge.

Beirne, P. \& South, N. (2007). Issues in Green Criminology. Confronting Harms against Environments, Humanity and Other Animals. Portland: Willan.

Biggs, D., Courchamp, F., Martin, R., \& Possingham, H. (2013, June 7). Legal trade of Africa's rhino horns. Science, 340, 1038-1039. Retrieved from http://max2.ese.upsud.fr/epc/conservation/PDFs/Rhinos.pdf

Bracken, M. \& Barkas, V. (2013, March 4). Vincent and Tumi of ProTrack discussing Rhino Poaching [Video file]. Retrieved from http://www.youtube.com/watch?v=NjdYHPZh5BY

Brand South Africa. (2012). South Africa's tourism industry. Retrieved from http://www.southafrica.info/business/economy/sectors/tourismoverview.htm\#.UtKX8WTuKFw

Brassett, B. (2014, February 28). Green Kidz learn about the bush. Kruger2Canyon News. Retrieved from http://kruger2canyon.linmedia.co.za/details/28-022014/green kidz learn about the bush/23499

Braun, D. (2012, November 8). U.S. pursues global strategy to end trafficking in wildlife. National Geographic. Retrieved from http://newswatch.nationalgeographic.com/2012/11/08/us-pursues-global-strategy-to-end-trafficking-in-wildlife/

Christy, B. \& Stinton, B. (2015). Warlords of Ivory. National Geographic Magazine, September, p. 25-59.

Clarke, R. (1997). Situational Crime Prevention: Successful Case Studies (2nd ed.). Guilderland, NY: Harrow and Heston.

Clarke, R. (2000). Situational Prevention, Criminology and Social Values. In A. Von Hirsch, D. Garland, \& A. Wakefield (Eds.), Ethical and Social Perspectives on Situational Crime Prevention (pp. 97-112). Oxford: Hart Publishing.

Clarke, R. \& De By, R. (2013). Poaching, habitat loss and the decline of neotropical parrots: a comparative spatial analysis. Journal of Experimental Criminology, 9, 333-353.

Cohen, L. \& Felson, M. (1979). Social Change and Crime Rate Trends: A Routine Activity Approach. American Sociological Review, 44(4), 588-608.

Conway-Smith, E. (2014, April 27). 20 years since Apartheid: What's changed in South Africa and what hasn't. Global Post.

Cornish, D. (1994). The procedural analysis of offending and its relevance for Situational Prevention. In R. V. Clarke (Ed.), Crime Prevention Studies (pp. 151-196). Monsey, NY: Criminal Justice Press.

Cornish, D. \& Clarke, R. (1985). Modeling Offenders' Decisions: A framework for research and policy. Crime and Justice, 6, 147-168.

Cornish, D. \& Clarke, R. (1986). The reasoning criminal: Rational Choice Perspectives on offending. New York: Springer Verlag.

Cornish, D. \& Clarke, R. (1987). Understanding Crime Displacement: an application of Rational Choice Theory. Criminology, 25(4), 933-947.

Cornish, D. \& Clarke, R. (2003). Opportunities, Precipitators and Criminal Decisions: a reply to Wortley's Critique of Situational Crime Prevention. Crime Prevention Studies, 16, 41-96.

Corruption Watch South Africa. (2014). Who can help? Retrieved from http://www.corruptionwatch.org.za/content/who-can-help 
DeFranza, D. (2010, August 18). The problem with "shoot to kill" conservation. Treehugger. Retrieved from http://www.treehugger.com/natural-sciences/the-problem-with-shootto-kill-conservation.html

Dewalt, K., Dewalt, B., \& Wayland, C. (2010). Participant Observation. In Participant Observation: A guide for fieldworkers (pp. 259-299).

Endangered Wildlife Trust. (2013). Position statement on legalizing the international trade in rhino horn. Retrieved from http://www.ewt.org.za/programmes/LPP/Doc/International\%20Trade Rhino\%20Horn Final.pdf

Faure, M. (2009). Environmental Crimes. Criminal Law and Economics, 320-345.

Financial Transparency Coalition. (2013). How the Groenewald Gang made millions off illicit wildlife trafficking. $\quad$ Retrieved from http://www.financialtransparency.org/2013/01/30/how-the-groenewald-gang-mademillions-off-illicit-wildlife-trafficking/

Foley, J. (2013). Elephant and rhino poaching increasingly linked to terrorist groups. Nature World News. Retrieved from http://www.natureworldnews.com/articles/4212/20130928/elephant-rhino-poachingincreasingly-linked-terrorist-groups.htm

Gibbs, C., Gore, M., McGarrell, E., \& Rivers III, L. (2009, July 16). Introducing Conservation Criminology - towards interdisciplinary scholarship on environmental crimes and risks. British Journal of Criminology, 1, 1-21.

Gosling, M. (2006, April 17). Future of SA's green court in the balance. IOL News. Retrieved from http://www.iol.co.za/news/south-africa/future-of-sa-s-green-court-in-the-balance1.274307\#.U2YmV61 sxk

Hauck, M. \& Sweijd, N. (1999). A case study of abalone poaching in South Africa and its impact on fisheries management. ICES Journal of Marine Science, 56, 1024-1032.

Huisman, W. \& Van Erp, J. (2013). Opportunities for environmental crime: a test of Situational Crime Prevention Theory. British Journal of Criminology, 53, 1178-1200.

Interpol. (n.d.). Environmental Crime. Retrieved from http://www.interpol.int/Crimeareas/Environmental-crime/Environmental-crime

Johannesen, A. B. \& Skonhoft, A. (2004). Tourism, poaching and wildlife conservation: what can integrated conservation and development projects accomplish? (Norwegian University of Science and Technology - Department of Economics). Retrieved from Norwegian University of Science and Technology Working Papers Website: www.ntnu.edu/econ/working-papers

Kalron, N. \& Crosta, M. (2015). Africa's White Gold of Jihad: al-Shabaab and Conflict Ivory. Elephant Action League. Retrieved from http://elephantleague.org/project/africaswhite-gold-of-jihad-al-shabaab-and-conflict-ivory/

K2C. (2013). Environmental Monitor project creates jobs and improves conservation actions. June 21. Kruger 2 Canyon News. http://kruger2canyon.linmedia.co.za/details/21-062013/k2c environmental monitor project creates jobs and improves conservation acti ons/19662

Kvinta, P. (2014). The madness of modern-day poaching. Retrieved from http://www.outsideonline.com/outdoor-adventure/nature/Hornswoggled.html

Leader-Williams, N. \& Milner-Gulland, E. (1993). Policies for the enforcement of wildlife laws: the balance between detection and penalties in Luangwa Valley, Zambia. Conservation Biology, 7(3), 611-617. 
Lynch, M. \& Stretsky, P. (2003). The meaning of green: contrasting criminological perspectives. Theoretical Criminology, 7(2), 217-238.

Matsueda, R., Kreager, D., \& Huizinga, D. (2006). Deterring delinquents: a Rational Choice Model of theft and violence. American Sociological Review, 71, 95-122.

Menna, W. (2008). An overview of the Chicago School Theories of criminology. Retrieved from http://www.sciences360.com/index.php/an-overview-of-the-chicago-school-theoriesof-criminology-21561

Messer, K. (2000). The poacher's dilemma: the economics of poaching and enforcement. Endangered Species Update, 17(3), 50-56.

Messer, K. (2010). Protecting endangered species: when are shoot-on-sight policies the only viable option to stop poaching? Ecological Economics, 69(12), 2334-2340.

Munusamy, R. (2013, March 1). Rhino poaching: it's war! Daily Maverick. Retrieved from http://www.dailymaverick.co.za/article/2013-03-01-rhino-poaching-itswar/\#.U2YaPq1 sxk

Oskamp, S. (2000). A sustainable future for humanity? - How can Psychology help? American Psychologist, 55(5), 496-508.

Petrossian, G. (2012). The Decision to Engage in Illegal Fishing: An Examination of Situational Factors in 54 Countries. Rutgers University-Graduate School-Newark.

Petrossian, G. (2014). Preventing Illegal, Unreported and Unregulated (IUU) Fishing: A Situational Approach. Biological Conservation. Online first

Pires, S. \& Clarke, R. (2012). Are parrots CRAVED? An analysis of parrot poaching in Mexico. Journal of Research in Crime and Delinquency, 49(1), 122-146.

Pires, S. \& Moreto, W. (2011). Preventing wildlife crime: solutions that can overcome the 'Tragedy of the Commons'. European Journal of Criminal Policy Research, 17, 101-123.

Poudyal, M., Rothley, K., \& Knowler, D. (2009). Ecological and economic analysis of poaching of the greater one-horned rhinoceros (Rhinoceros unicornis) in Nepal. Ecological Applications, 19(7), 1693-1707.

Pro Track. (2011). Pro Track Anti-Poaching Unit. Retrieved from http://www.protrackapu.co.za

Rademeyer, J. (2012a). Killing for Profit: Exposing the Illegal Rhino Horn Trade. Cape Town, South Africa: Zebra Press.

Rademeyer, J. (2012b). Rhino butchers caught on film at North West Game Farm. Mail \& Guardian Online. Retrieved from http://mg.co.za/article/2012-11-08-rhino-butcherscaught-on-film

Rademeyer, J. (2012c). The "Boeremafia". In Killing for Profit: Exposing the Illegal Rhino Horn Trade (pp. 127-150). Cape Town, South Africa: Zebra Press.

Rettet das Nashorn. (2014). Shaya. Retrieved from http://www.rettet-das-nashorn.com/wasbislang-geschah/hund-shaya/

Rhino Mercy. (2013). US Secretary of State Hillary Clinton keynote speech on wildlife trafficking [Video file]. Retrieved from http://rhinomercy.org/video--photo-gallery.html

Rhino Rescue Project. (2012b). Retrieved from http://www.rhinorescueproject.com

Rhinomercy. (2014). Why the rhino? Retrieved from http://rhinomercy.org/

Save the Rhino. (2015). RIP Dr. Ian Player. Retrieved from

https://www.savetherhino.org/latest news/news/1166 rip dr ian player 
Sharife, K. (2013). Is it time to legalise rhino horn trade? Le Monde Diplomatique. Retrieved from http://mondediplo.com/openpage/is-it-time-to-legalise-rhino-horn-trade

Sills, J. (2013). Letters to the Editor - Rhino poaching: supply and demand uncertain [Entire issue]. Science, 340, 1167.

Sollund, R. (2013). Animal Abuse, Animal Rights and Species Justice. Paper presented at The American Society of Criminology, Atlanta, GA. Retrieved from https://asc41.com/Annual Meeting/2013/Presidential\%20Papers/Sollund\%20Animal \%20Abuse.pdf

South African Department of Environmental Affairs. (2014). Strategic issues: job creation. Retrieved from https://www.environment.gov.za/strategicissues/jobcreation

South, N., Brisman, A., \& Beirne, P. (2013). A guide to a green criminology. In N. South, \& A. Brisman (Eds.), Routledge International Handbook of Green Criminology (pp. 27-42). New York City, NY: Routledge.

TRAFFIC. (2013). Rhino horn consumers, who are they? Retrieved from file:///Users/Skippy/Downloads/Consumers factsheet FINAL.pdf

The International Rhino Foundation. (2014). How long can a rhino's horn grow? Retrieved from https://intlrhinofoundation.wordpress.com/2010/07/12/how-long-can-a-rhinos-horngrow/

The Law Library. (2014). Wildlife trafficking and poaching: South Africa. Retrieved from http://www.loc.gov/law/help/wildlife-poaching/southafrica.php\# ftn27

The Library of Congress. (2015). Firearms - Control Legislation and Policy: South Africa. Retrieved from http://www.loc.gov/law/help/firearms-control/southafrica.php

US Legal Inc. (2001-2014). Poaching Law \& Legal Definition. Retrieved from http://definitions.uslegal.com/p/poaching

Warchol, G. L. (2004). The transnational illegal wildlife trade. Criminal Justice Studies: A Critical Journal of Crime, Law and Society, 17(1), 57-73.

White, R. (2003). Environmental issues and the criminological imagination. Theoretical Criminology, 7(4), 483-506.

White, R. (2011). Transnational Environmental Crime - Toward an eco-global criminology. New York, NY: Routledge.

World Wildlife Fund. (n.d.). Black rhino range expansion project. Retrieved from http://www.wwf.org.za/what we do/rhino programme/black rhino/

Wyatt, T. (2009). Exploring the Organization of Russia Far East's Illegal Wildlife Trade: Two Case Studies of the Illegal Fur and Illegal Falcon Trades. Global Crime, 10(1-2), 144-154.

YES! Media. (2012). The local government handbook - Maruleng local municipality. Retrieved from http://www.localgovernment.co.za/locals/view/131/maruleng-local-municipality

Yin, R. (2009). Case Study Research: Design and Methods. 4th ed. Thousand Oaks (CA): Sage. 